\title{
Urban hierarchy inside a divided urban system of Bosnia and Herzegovina
}

\section{Bosna Hersek'in parçalanmış kentsel sistemi içindeki kentsel hiyerarşi}

\author{
Haris GEKIĆ ${ }^{1} \oplus$, Aida BIDŽAN-GEKIĆ ${ }^{2}$ ()
}

${ }^{1}$ University of Sarajevo, Faculty of Science, Department of Geography, Sarajevo, Bosnia and Herzegovina

${ }^{2}$ University of Sarajevo, Faculty of Science, Department of Geography, Sarajevo, Bosnia and Herzegovina

ORCID: H.G. 0000-0002-7055-6608; A.B.G. 0000-0002-3980-9750

\begin{abstract}
Within the framework of the analysis of basic features of the urban system of Bosnia and Herzegovina, its insufficient development with the pronounced predominance of smaller urban settlements is highlighted (more than $65 \%$ of urban settlements have less than 10000 inhabitants). Evident polarization in the urban system of Bosnia and Herzegovina is reflected in the very dynamic monocentrism of the capital city and the regional centers, which is further intensified by the consequences of the war through the resettlement of a large number of refugees and displaced persons. One of the main objectives of this paper is the realization of nature and the change in the level of the urban hierarchy in Bosnia and Herzegovina by determining changes in urbanization and the present differences between urban settlements in a period longer than 30 years (1981-2013).

A further analysis of the interdependence of the urban system of Bosnia and Herzegovina and the territorial organization has determined that the urban system of Bosnia and Herzegovina did not represent the basis of the formation of a new political-territorial organization. The dissolution of integrative urban development after 1991 has markedly negative tendencies in the development of the urban system, which has been shown in the last two decades. Keywords: urbanization, Zipf's law, urban development.
\end{abstract}

\section{ÖZ}

Bosna-Hersek'teki kentsel sistemin temel özelliklerinin analizi çerçevesinde daha küçük kentsel yerleşimlerin belirgin baskınlığı ile yetersiz gelişimine dikkat çekmektedir (kentsel yerleşimlerin\% 65'inden fazlasının 10.000'den az nüfusu bulunmaktadır). Bosna-Hersek'in kentsel sistemindeki belirgin kutuplaşma, başkentin ve bölgesel merkezlerin çok sayıda mültecinin ve yerlerinden edilmiş kişilerin yeniden yerleştirilmesiyle savaşın sonuçlarının daha da yoğunlaştığı çok dinamik monokentizmine yansıtmaktadır.

Bu yazının temel amaçlarından biri, 30 yıldan daha fazla süren bir dönemde (1981-2013) oluşan kentleşmedeki değişimleri ve kentsel yerleşimler arasındaki mevcut farkları belirleyerek Bosna-Hersek'teki kentsel hiyerarşi kapsamındaki değişimlerinin tespit edilmesidir. Bosna-Hersek kentsel sisteminin ve bölgesel teşkilatın birbirine bağımlılığının bir başka analizi, Bosna Hersek'in kentsel sisteminin yeni bir siyasi-bölgesel teşkilatı oluşumunun temelini temsil etmediğini belirlemiştir. 1991'den sonra bütünleştirici kentsel kalkınmanın çözülmesi, son yirmi yılda gösterilen kentsel sistemin gelişiminde belirgin olumsuz eğilimlere sahiptir.

Anahtar Kelimeler: kentleşme, Ziponun hukuku, kentsel gelişim. 


\section{INTRODUCTION}

\subsection{Literature review}

The concept of Urban System was introduced by Brian Berry (1964). Urban system is defined as any network of interdependent urban places. The nature of interdependence among urban place may be economic, political, social or cultural. The urban hierarchy concept considers that the urban places vary in population sizes and economic functions (Vresk, 1991).

Rank size rule was proposed by Zipf (1949). According to rank size rule there is regularity in the distribution of cities of varying sizes. Number of settlements and their size in an urban system are determined by forces of unification and the forces of diversification. Some authors (Harvey, 1973; Lefebvre, 1996; Brenner et al., 2012) discuss that cities are main founding points for the production, circulation, and consumption of provisions, and their sociospatial organization, governance systems, and forms of socio-political conflict have to be understood in relation to this role. A scientific discussion of Zipf's law was presented in many papers. In the last two decades especially by Gabaix (1999), Gabaix and Ioannides (2004), Nitsch (2005), Chen (2016).

Biggote et al. (2014) presented a statistical study of the relationship between urban hierarchy and population dynamics in Portugal and note that their study provides evidence on the linkage between the changes in the amount of population covered by a population centre and the population dynamics in future periods. Dimou and Schaffer (2009) in their study on the urban hierarchy in the Balkans conclude that during the 1981-2001 period, medium-sized cities demographics resisted external shocks due to conflicts, redrawing of national frontiers and institutional upheaval better then large conglomerations. Jażdżewska (2017) in application of rank-size rule on urban system of Poland concludes that application of the Zipf rule, especially from a dynamic perspective, must be accompanied by a good knowledge of the history of the region under research and the formation of urban settlement networks within it. In her study, Dokmeci (1986) concludes that the adjustment of the system of cities in Turkey according to the rule of size order over the period 1945-1975 is parallel to the economic development of the country, while Kundak and Dokmeci (2018) in the study of mobility in the ranking of cities by size for the period 2000-2012 reveal that the upper level of the hierarchy of cities is more stable than the hierarchy of smaller cities.

The concept of primate city was first introduced by Jefferson (1939); it gives the relationship between the population size and functions of the largest city with the other cities in a country. The concept of primate city as given by Jefferson was based on the fact that primate city is the largest by more than twice than the second ranked city. For Servet Mutlu (1989) primacy means that the size of the biggest city in a country is disproportionately large when compared to the size of the second largest city. According to Mokhtar (2013) geographical space of Sultanate of Oman is very polarized by the first city.

According to Chen and Lu (2015) cross-country analysis in China indicates that the population size of the primary city is smaller than its predicted value and there is a distortion of city size toward small cities. Some authors think that primate cities are engines of economic growth (Young-Hyun et al, 2010) and believe that population dispersion among cities is suboptimal, at least during some stages of urbanization (Hadar et al., 2004). For Đerčan et al. (2017) the results of urban primacy analysis for Serbia shows a very high urban primacy index, where the remaining cities in the hierarchy are lagging behind the primate city (Belgrade). The characteristics of the primate city have been observed in many developing countries such as the Latin American countries of Peru, Argentina and Uruguay (Waugh, 2000). According to Kumari (2015) the distribution of cities in India seems to systematically reject Zipf's law.

In order to understand the pattern in the distribution of urban settlements this paper focuses on the rank size relationship and the primacy pattern of Bosnian urban system.

\subsection{THE STUDY AREA}

The country of Bosnia lasts for more than a thousand years, regardless of the forms of government on its soil. All present-day states in the Western Balkans have had a longer or shorter state and legal discontinuity in their history. The people of Bosnia, regardless of their religious and later ethnic background, earlier and today form the political nation of Bosnia today (Ibrahimagić, 2014). 
Bosnia and Herzegovina is a contemporary name of an independent and internationally recognised state (from 6 April 1992) and 177th member of the United Nations (from 22 May 1992) within the existing borders. Bosnia and Herzegovina is a country of Southeast Europe. It stretches over the western end of the Southeast Europe, and opens to the Adriatic Sea along a $24.4 \mathrm{~km}$ coastline in the area of NeumKlek. Bosnia and Herzegovina occupies an area of $51,209.2 \mathrm{~km}^{2}$. It falls within the group of geographically small countries. On a list of 44 countries of Europe arranged by area, Bosnia and Herzegovina ranks 25th. With regards to population, it ranks 28th immediately following the Republic of Ireland (4.3 million), Croatia (4.1 million) and Moldova (3.6 million). With a population density of 69 people/ $\mathrm{km}^{2}$, Bosnia and Herzegovina falls close to the European average, (the European average being 72 people $/ \mathrm{km}^{2}$ ), ranking 26th. Due to the specificity of the relief, the population lives in a rather fragmented settlement system comprised of 6.141 settlements of uneven population density (Census of population, 2013; The World Factbook, 2019).

Bosnia and Herzegovina after 1995 is governed by the Dayton Peace Agreement, according to which it comprises two Entities and one District, the Federation of Bosnia and Herzegovina (comprised of 10 Cantons) and Republic of Srpska, and a Brčko District, which was established by a special decision of the International Court of Arbitration of 2000. The Statistics Agency of Bosnia and Herzegovina has published the official results of the 2013 Population Census, and according to these internationally comparable data, Bosnia and Herzegovina has a population of 3,531,159, of which 2,219,220 or 62.85\% live in the entity of Federation of Bosnia and Herzegovina, 1,228,423 or 34.79\% in the entity of Republic of Srpska, and 83,516 or 2.36\% in Brčko District. Majority of population in Bosnia and Herzegovina by religion are muslims $(50,7 \%)$. When it comes to the language used by residents, Bosnian language speaks around 53\%, Serbian 30.76\%, and Croatian 14.6\% of total population (Census of population of Bosnia and Herzegovina, 2013).

GDP data measured by purchasing power show that in the 2017 GDP of Bosnia and Herzegovina per capita was approximately US \$ 12,700. Only Albania had a somewhat lower GDP per capita in the South East Europe region. As regards regional development, Bosnia and Herzegovina is immediately behind Montenegro, Serbia and North Macedonia. The GDP per capita of Bosnia and Herzegovina accounts for only 33\% of GDP per capita of the EU. GDP growth is estimated at 3\% per annum. Foreign direct investments account for $2.2 \%$ of GDP. According to the Statistics Agency, the working-age population of Bosnia and Herzegovina is approximately 2.4 million, of which 822,000 or $34.4 \%$ are in active employment. About $56 \%$ of employees work in the tertiary sector, $30 \%$ in the secondary and 14\% in the primary sector of economy (Agency for Statistics of Bosnia and Herzegovina, 2019; The World Factbook, 2019).

Bosnia and Herzegovina had 109 municipalities, 5,825 settlements, 105 urban settlements in 1991. After 1995 Bosnia and Herzegovina has two entities, one District (Brčko), number of municipalities was increased on 143 (79 in Federation of Bosnia and Herzegovina; 64 in Republic of Srpska), number of settlements on 6.141 and number of urban settlements on 110 (65 in Federation of Bosnia and Herzegovina; 44 in Republic of Srpska; 1 in Brčko District). According to the amendments to the regional Laws on Territorial Organization in Bosnia and Herzegovina after 2006, in June 2019, there is 24 official cities (not urban settlements, but on same administrative level as municipalities mostly). Two main regions (entities) have different laws on cities. One municipality in whole can become city or two or more municipalities can form one city. Politically controversial laws with no real benefits for municipality to acquire city status except cosmetic ones (some cities have less than $30 \%$ percent of urban population in whole city area with only one small urban settlement) (Figure 1). 


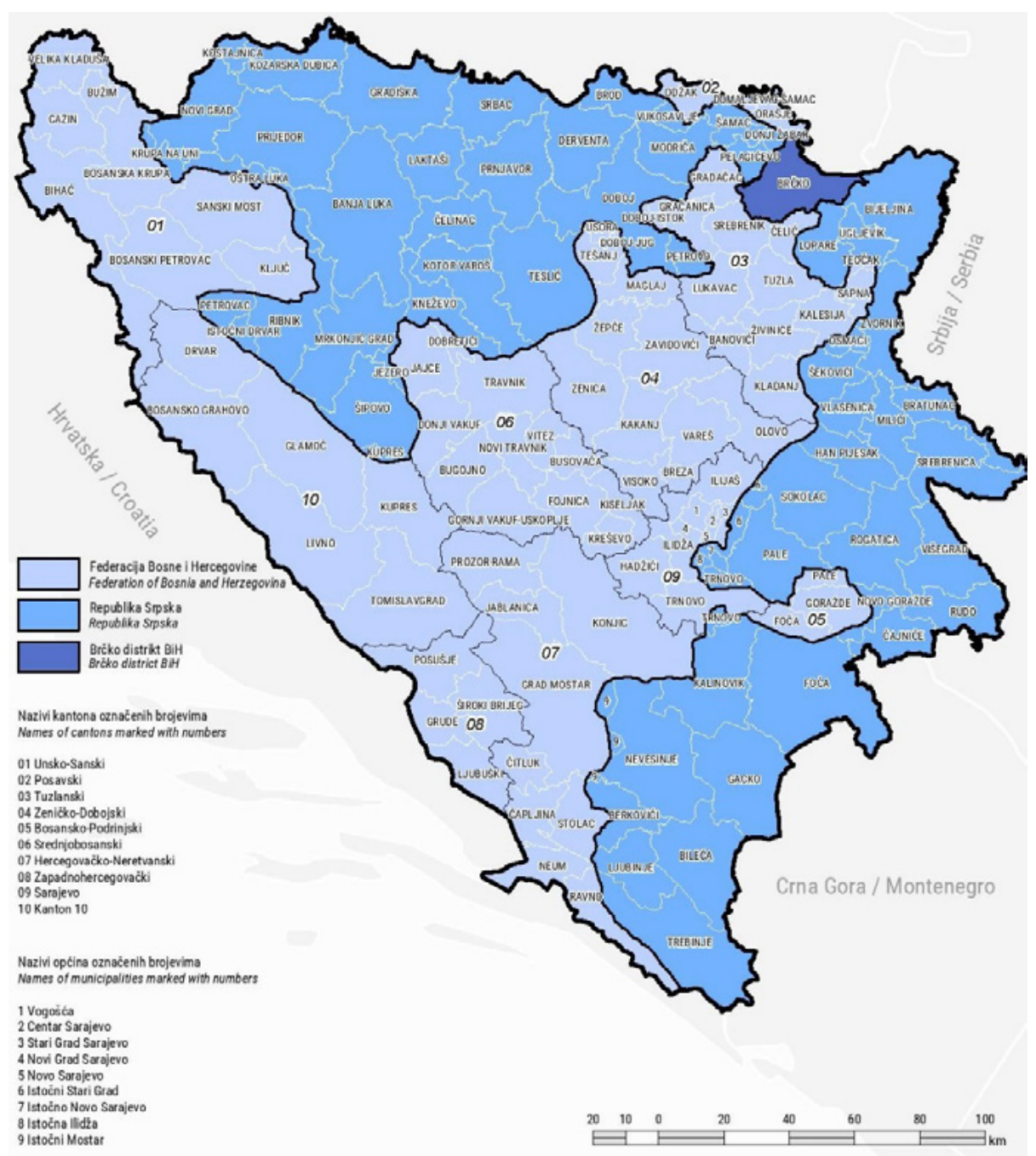

Figure 1: Administrative and territorial structure of Bosnia and Herzegovina Source: Census of population, 2013

The organization of paper is as follows. The second part deals with a brief overview of the urbanization process in Bosnia and Herzegovina, the third with methodology, the fourth with results and a discussion with reference to the implications of the contemporary political and geographical structure of Bosnia and Herzegovina on the urban system, and the final section concludes.

\section{REVIEW of URBANIZATION in BOSNIA and HERZEGOVINA}

In Roman times, the largest number of known urban centers in the area of Bosnia and Herzegovina developed on an indigenous basis. This does not in any way mean that the Roman urban settlement always originated in the place where the indigenous settlement existed, but the fact is that the settlements with the status of a city (municipium) were regularly located in areas that preserved significant traces of settlement before the arrival of the Romans. Well known municipium's in the territory of Bosnia and Herzegovina were: Domavia (colony from the middle of the 3rd century BC), Bistue nova, Bistue vetus, Diluntum, Splonum, Salviae, Pelva (Pašalić, 1960).

There were 25 open urban settlements with the functions of mining, crafts, trade and administration in the medieval Bosnian state in the 14th century, and 40 in the 15th century. According to the defter of the Ottoman Empire in 1468/69, it can be concluded that the largest urban the settlement of Bosnia was Fojnica with a population of 1,665 residents. In fact, only since the mid-14th century, the accelerated development of the European economy and the conjuncture of metals in its market have created the basic conditions for the emergence of urban settlements in medieval Bosnia. In general, mining played a major role in the economic, political and cultural development of medieval Bosnia (Kovačević-Kojić, 1978). 
In the middle of the 17th century Sarajevo was the most important city of the Ottoman Empire in the Balkans with a population of about 80,000 residents. However, in the fundamentally changed circumstances of the political economic and cultural civilization structure of the Turkish period, there is a very rapid and comprehensive establishment of new and development of existing urban centers. Their number has tripled. The intensified urbanization is a consequence of the complex action of numerous factors such as more widespread economic, administrative-political and cultural activities in the tightly organized Turkish feudal system and the prominent geographical and strategic position of Bosnia and Herzegovina in the territorial part of the Ottoman states. An important factor in this was the strong Islamization when, as recently established, more than two-thirds of the Bosnian population were Muslim in the first half of the 17th century (Sućeska, 1968).

It should be emphasized at the outset that the urbanization of Bosnia and Herzegovina in the Turkish period is a consequence of the complex effects of many factors. It is particularly important to note that urbanization is not only a consequence of better developed productive forces in the better organized feudal system of the Turkish Empire but also a consequence of phenomena emanating from the political, social and cultural-civilizational structure of the new state (Bakaršić, 1961). The motives for urbanization of Bosnia and Herzegovina during the Turkish era are: favoring cities according to Islam regulations, the geographical position of Bosnia as the most prominent Turkish province in Europe, the necessity of organizing traffic in a spatially large state, the developed craft for the great needs of numerous Turkish armies, etc. (Bakaršić, 1973).

At the turn of the nineteenth and twentieth centuries, the cities in Bosnia and Herzegovina developed unevenly, with many local and regional features, whether they were external visible, or internal less visible elements. Some of them became important industrial centers and gradually took the form of a European industrial city (both in social structure and appearance - Tuzla, Zenica), while most remained on crafts, small entrepreneurship (with modern crafts) and increased trade and traffic. (Hadžibegović, 2004). During the rule of AustroHungary (1878-1918), the construction of railways was especially emphasized, which encouraged faster development of urban centers and the emergence of new ones in the area of mining resources. Until the second half of the nineteenth century, Bosnia and Herzegovina lived in the lethargy of the Ottoman social system, and it was only with the establishment of Austro-Hungarian rule that significant industrial development began in this region. The industrial enterprises erected from 1878 to 1919 would represent, even in the period between the two wars, the base of Bosnia and Herzegovina's industry, and would significantly determine its development after the Second World War, since until 1948 in Bosnia and Herzegovina were restored only those industries and those industrial enterprises that were built in this region by the Austro-Hungarian authorities (Kamberović, 1998).

Between the two world wars, the urbanization process in Bosnia and Herzegovina stagnated (only $2 \%$ of the working population worked in industry). In World War II, many urban settlements suffered extensive damage. After World War II, rapid industrialization and urbanization took place. With the rapid and versatile development in the first place of industrial and then tertiary activities in the socialist period, the process of urbanization in all its manifestations was intensified, where the construction of road and railway roads was of particular importance. Although the increase in urban population results from the immigration of rural population into cities, these changes are to a certain extent due to the increased number of urban settlements from 1953 to 1961, due to the city new definition being applied. The increase in urban population was largely dependent on the magnitude of migration movements and less influenced by the natural increase in urban population. In the context of rapid economic development, industrial and urban centers were increasingly attracted to the population from closer and further surroundings, and the migration of population from villages to cities (related to industrialization and changing economic composition of the population) was a characteristic phenomenon in this period. Population migration towards cities has led to a much faster increase in urban population than was the increase in the total population of Bosnia and Herzegovina.

The most dynamic changes in the period of the strongest industrialization up to 1981 were next to the cities and its settlements in the immediate vicinity as well as along the main roads. In this period there was recorded a weak, still insufficient diversification of rural municipalities manifested by reducing the share of the active population in the primary, and increasing the number of employees in the secondary and tertiary sectors (Gekić and Bidžan-Gekić, 2016).

From 1992 to 1995, about 35\% of housing units in Bosnia and Herzegovina were partially or completely destroyed. Of this number, almost $80 \%$ of the housing units were either destroyed or badly damaged. From the beginning of the war to the signing of the General Framework Agreement for Peace in Bosnia and Herzegovina (the Dayton Peace Agreement), about 2.2 million persons have been raised from their pre-war homes in Bosnia and Herzegovina, representing more than 50\% of the pre-war domicile population (Ministry of Human Rights and Refugees of Bosnia and Herzegovina, 2006). Total direct and indirect war damage to the economy was estimated at around 
US \$115 billion market value, with these damages being more pronounced in the so-called "invisible capital" (lost markets, technological obsolescence, privatisation, telecommunications, IT, management, marketing) (stagnation in science, currently less than 0,2\% of GDP goes to science, high brain drain rate, during the war $40 \%$ scholars left the country). Due to the war, Bosnia and Herzegovina lags some 20 years behind other average countries in transition, which significantly affects its international competitiveness. In the spheres of science, technology and information, this lag is even more pronounced (Bašić, 2006).

The urbanization pattern in Bosnia and Herzegovina is mainly oriented to larger cities. The Bosnia and Herzegovina is going through intensive processes of depopulation and demographic aging, with pronounced regional disproportions of the population. Bosnia and Herzegovina is insufficiently urbanized. In the period from the first official census during the Austro-Hungarian rule in Bosnia and Herzegovina, the total population grew from 1.16 million to 1.9 million by the beginning of World War I (Table 1; Figure 2).

Table 1. Urban population in Bosnia and Herzegovina, 1879-2013

\begin{tabular}{ccc}
\hline Census years & Population (millions) & Urban (\%) \\
\hline $\mathbf{1 8 7 9}$ & 1.16 & 12.8 \\
$\mathbf{1 8 8 5}$ & 1.34 & 13.2 \\
$\mathbf{1 8 9 5}$ & 1.57 & 13.5 \\
$\mathbf{1 9 1 0}$ & 1.90 & 14.6 \\
$\mathbf{1 9 2 1}$ & 1.90 & 12.5 \\
$\mathbf{1 9 3 1}$ & 2.32 & 10.1 \\
$\mathbf{1 9 4 8}$ & 2.56 & 10.8 \\
$\mathbf{1 9 5 3}$ & 2.85 & 12.7 \\
$\mathbf{1 9 6 1}$ & 3.28 & 20.6 \\
$\mathbf{1 9 7 1}$ & 3.75 & 26.2 \\
$\mathbf{1 9 8 1}$ & 4.12 & 33.6 \\
$\mathbf{1 9 9 1}$ & 4.38 & 39.7 \\
$\mathbf{2 0 1 3}$ & 3.53 & 42.5 \\
\hline
\end{tabular}

Source: own calculations; Census of population, 1879-2013

The share of urban population was very low and ranged from 12.8-14.6\%. The urban population growth rates were constantly higher than the total population growth rate, so in the period 1895-1910 the urban population grew at an annual average rate of $2.1 \%$ and the total population at an average annual rate of $1.4 \%$. Then between the two world wars, due to the economic policy of the country's development and orientation towards agriculture, the share of urban population declined to $10.1 \%$ in 1931, and after the Second World War in 1948 to $10.8 \%$. The total population increased from 2.32 million in 1931 to 2.56 million in 1948. At the same time, urban population growth averaged $1.1 \%$ annually, compared to $0.6 \%$ of the average annual population growth. In the period 1953-1961 the share of urban population increased from $12.7 \%$ to $20.6 \%$, while the average annual growth rate of urban population was $10.8 \%$ compared to the average annual growth rate of the total population of $1.9 \%$.

In the period 1961-1991, the total population increased from 3.28 million to 4.38 million at an average annual rate of $1.1 \%$, while the share of urban population increased from $20.6 \%$ to $39.7 \%$, from 657,275 to $1,737,797$ at an average annual rate of as much as $5.2 \%$. In this period, the urban population increased by 2.6 times in 30 years. According to the estimates of the Agency for Statistics of Bosnia and Herzegovina, after the 1992-1995 war, Bosnia and Herzegovina had about 732,000 less of the total population (16.7\% less) and about 190,000 less of the urban population (10.8\% less) in 1996 compared to 1991. This is due to the suffering of the population, emigration from outside the country and the relocation of the population from villages to cities.

The total share of urban population is $42.5 \%$ in 2013 , which is $2.8 \%$ more than in 1991 . However, essentially the urban population is down by about 240,000 . If we take into account the estimated number of inhabitants from 1996, we can conclude that the number of urban population in Bosnia and Herzegovina is smaller by one large city of 50,000 inhabitants, and in comparison with 1991 by a city the size of Sarajevo from 2013. After 1996, there is a stagnation in the increase in urban population share. Bosnia and Herzegovina in last interval between census 1991 and census 2013 saw growth of share of urban population in total population by 2,8\% mostly because decrease in total population was higher than decrease in urban population $(-19,3 \%$ and $-13,7 \%)$. 


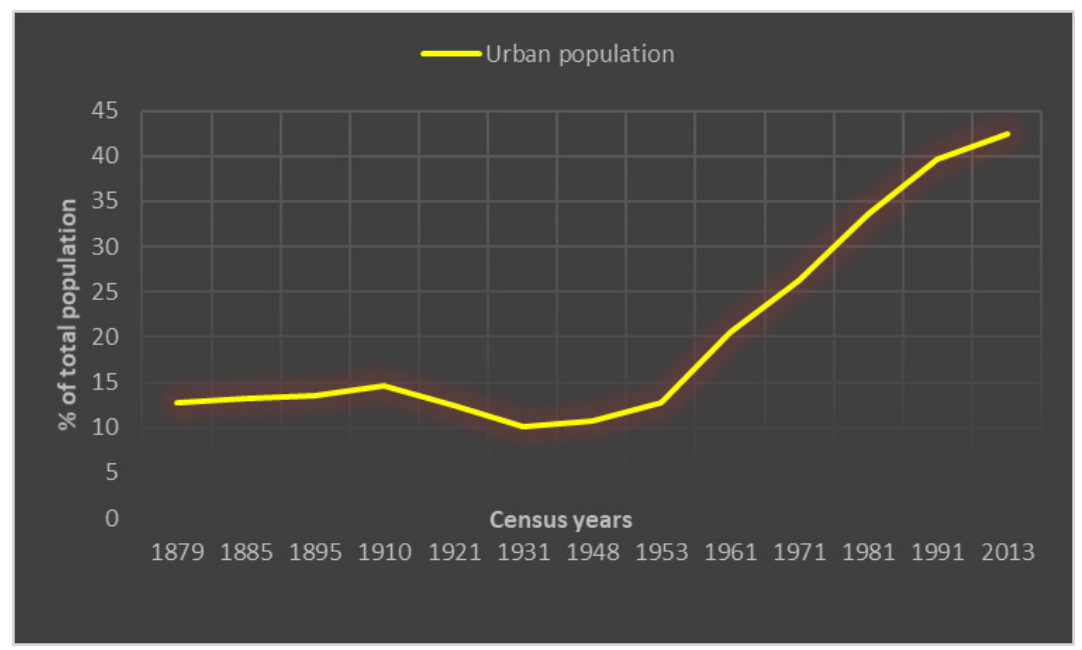

Figure 2: Urban population of Bosnia and Herzegovina

Some of the main characteristics of contemporary urban development in Bosnia and Herzegovina after period of war which lasted from 1992-1995 are: strong regional disparity in the recent urban development, which is reflected in uneven urban population distribution within Bosnia and Herzegovina; strong demographic growth of urban areas and strong depopulation of rural areas; spatially differentiated concentration and polarization of the demographic development of Bosnia and Herzegovina. In 2013, the largest urban settlements in Bosnia and Herzegovina were: Sarajevo with a population of 271,194, Banja Luka with 138,963, Tuzla with 74,457, and Zenica with 70,553 . There is a total of 16 urban settlements with populations in excess of 15,000 , more than half of which are situated in the north and only two in the south, and not a single one in the east or west part of our country (Census of population of Bosnia and Herzegovina, 2013).

\section{METHODOLOGY}

The main units of the study are the settlements of Bosnia and Herzegovina which have the official status of urban settlements according to the officially used statistical register. The aim of this paper is to determine and analyze the urban hierarchy (ranked order of urban settlements based on population size) in Bosnia and Herzegovina using census data (from 1981-2013), and to analyze the pattern of primacy and the rank size distribution of urban settlements. The analysis of different size categories of urban settlements using the rank size rule and the law of the primate city contributes to a better understanding of the urbanization process and its flows in Bosnia and Herzegovina in the modern period. This research helps to understand how urban settlements of different class categories are positioned in the urban hierarchy. The main task is analysis of population sizes of urban settlements in order to draw conclusions about their fluctuation, taking into account historical events and economic, sociological, cultural, environmental and other causes.

In discussion part we specifically looked at the issues relating to institutional assumptions for urban spatial planning in Bosnia and Herzegovina to provide more complex analysis of urban hierarchy. Since the 1981 census, the administrative and legal criteria have been used to determine and declare the type of settlement in Bosnia and Herzegovina through legal regulations. The settlements are divided into two groups: urban and other. It was allowed for a local level, a municipality, to designate a settlement as urban if it has historical or tourist significance or constitutes an important protected urban heritage. In the 2013 census, the Agency for Statistics kept the types of settlements that were in 1991.

To show the evolution of the distribution of urban settlements of different sizes over time, we analyzed the size and number of urban settlements by dividing them into 6 classes by population number for 1981, 1991, and 2013 with respect to the average urban settlement size of: I (100,000+) - metropolis, II (50,000-99,999) - regiopolis, III (20,000-49,999) - big city, IV (10,000-19,999) - mid city, V (5,0009,999) - small city, VI (below 5,000) - microcity.

The rank size rule refers to the existence of dependence between the size and the number of cities, that is, the tendency of creating the regular rank of the size of cities in the space. These observations were elaborated later by many authors: Zipf, Stuart, Singer, Berry. These interdependencies were theoretically formulated as the Rank size rule (Berry and Garrison, 1958; Soo, 2005). According to this, 
it can be expected that one city in a set of cities of a country or region, ranked by size, will have as many inhabitants as the largest city, divided by the city's rank in a set of cities. Therefore, the second settlement in a set will have half the population of the largest one, the third will have one third less than the largest, etc.

In an urban system, forces of diversification and unification work simultaneously, and they determine the relationship between size and number of settlements. A rank size distribution of cities is expected to indicate the economic development and an integrated urban system (Gregory and Urry, 1985).

Hence in the case of unification, nearness to the market is the determining factor in the location of settlements. The case of unification is opposite to the case of diversification where the sources of raw materials are the determining factor in the location of settlements. A large settlement constitutes a large market, hence tertiary activities tends to be concentrated in large cities. Even the secondary activities also tend to be concentrated in the large and metropolitan cities. These forces result in the emergence of a few very large cities (Das and Dutt, 1993). According to Zipf, it is called the forces of unification and it results in the emergence of small number of large service-oriented cities. Diversification tends to minimise the difficulty of moving raw materials to the places where they are to be processed; unification tends to minimise the difficulty of moving processed materials to the ultimate consuming populace (Berry and Garrison, 1958).

The rank-size rule for the number of inhabitants by cities known also as the Zipf's law is usually determined by the equation:

$$
\log (\mathrm{R})=\log (\mathrm{A})-\alpha \cdot \log (\mathrm{P})
$$

Here, $\mathrm{P}$ represents the population of a city. $\mathrm{R}$ is the rank of a city when cites are ranked from 1 to $\mathrm{n}$ by the population size. A and $\alpha$ are constants. $\alpha$ is also referred as Pareto exponent. Based on Pearson's correlation coefficient, the degree of matching of distribution of the settlements can be determined.

This theory says that if cities are ranked from largest to smallest populations, then the $r$ ranked city is expected to have a population equal to the top ranked city divided by the rank of that city. The rank-size rule says that when ranks of the cities are arranged in descending order and plotted against their populations (rank 1 being given to the largest, and so on) in a doubly logarithmic graph, a rank-size distribution results. If rank size rule fits in a country's urban system, the logarithmic figures will present a straight line.

Because of problems with serial correlation caused by the ranking procedure and with ordinary least squares estimation (the standard errors would be underestimated) Zipf's law can be rejected too often. To correct for these biases linked with the estimation of previous equation Gabaix and Ibragimov (2011) suggest to use 'Rank-1/2' as dependent variable and to estimate the following variation of previous equation:

$$
\log (\mathrm{R}-1 / 2)=\log (\mathrm{A})-\alpha \cdot \log (\mathrm{P})
$$

City size distribution is said to follow Zipf's law if the estimated value is statistically equal to 1 . In that case, the plot of the log of rank versus the log of city size shows a scatter diagram with a regression line having slope equal to -1 .

A value statistically equal to 1 would confirm that the city size distribution obeys a strict form of Zipf's law. A value statistically less than 1 indicates the city size distribution is more uneven where one or a few cities dominate the whole urban structure. This is also referred as primatial distribution. On the contrary, a value statistically higher than 1 indicates a more even city size distribution where the size difference between larger and smaller cities is little.

For research of rank size rule of urban settlements in Bosnia and Herzegovina the figures are drawn with $\ln ($ size) on the horizontal axis (size in measured in thousands) and $\ln ($ rank $-1 / 2$ ) on the vertical axis. The slope of the trendline drawn in the figures then provides an unbiased estimate of the slope of the rank-size rule (Gabaix and Ibragimov, 2011). If the slope of the line equals approximately to minus 1 the relationship is known as Zipf's Law. The figures also provide the $\mathrm{R}^{2}$ as an indication of goodness of fit and the two largest cities. For the rank size rule of urban settlements, we have taken into account urban settlements with more than 2,000 inhabitants (which reduces the number of total urban settlements in 1981 by 11, 1991 by 5 and 2013 by 11).

The American geographer Jefferson (1939) noted that in some countries, a capital city - a primate city is the largest and the other cities are considerably smaller, and this phenomenon was called the Law of the primate city. The largest city in a country is the primate city 
when it is at least more than two times the size of the second largest city. Many scientists believe that this is due to political and economic opportunities, and the exceptional political, economic and social significance of the capital (Mutlu, 1989; Vresk, 1991; Sarkar and Maji, 2013; Yousuf and Shah, 2014).

There are different methods to compute primacy index such as Urban primacy index, Two-city index, Ginsberg index and Four-city index or Mehta index. In this paper we used Mehta index also which is defined as: P1 / (P1+P2+P3+P4) where P1 is population of first ranked city, and P2, P3 and P4 of second, third and fourth (Mehta, 1964). Examining rank-size rule and four city index Richardson (1973) suggested ranges to determine primate city score: 0.41 and less (the least primacy), 0.41 to 0.54 (desirable primacy), 0.54 to 0.65 (high primacy) and 0.65 to 1 (extra primacy). The primacy index has been calculated for cities (urban settlements) of Bosnia and Herzegovina for the years 1981,1991 and 2013.

\section{RESULTS and DISCUSSION}

First in this section we analyse the distribution of urban settlements sizes in Bosnia and Herzegovina for the year 1981, 1991 and 2013. To define various class categories of cities we employed six classes of population size (Table 2).

Table 2. Number of urban settlements in classes, 1981-2013

\begin{tabular}{lccc}
\hline Class & $\mathbf{1 9 8 1}$ & $\mathbf{1 9 9 1}$ & $\mathbf{2 0 1 3}$ \\
\hline I (100.000 +) & 2 & 2 & 2 \\
II (50.000 - 99.999) & 3 & 3 & 4 \\
III (20.000 - 49.999) & 5 & 7 & 6 \\
IV (10.000 - 19.999) & 21 & 25 & 22 \\
V (5.000 - 9.999) & 27 & 34 & 33 \\
VI (below 5.000) & 45 & 34 & 43 \\
Total & 103 & 105 & 110 \\
\hline
\end{tabular}

Source: own calculations

The number of smallest urban settlements (VI class) decreased by 24\% from 1981-1991, while the number of small urban settlements (V class) increased by $26 \%$. At the same time, the share of urban population in the smallest group of urban settlements decreased from $9.5 \%$ to $6.2 \%$. Due to the war and related emigration movements, the number of urban settlements in the VI class increased by 9 , and the share of urban population in this group increased by $2.0 \%$ (Table 3 ).

Table 3. Urban population in classes of urban settlements (\%), 1981-2013

\begin{tabular}{lccc}
\hline Class & $\mathbf{1 9 8 1}$ & $\mathbf{1 9 9 1}$ & $\mathbf{2 0 1 3}$ \\
I (100.000 +) & 33.7 & 32.2 & 27.3 \\
II (50.000 - 99.999) & 13.8 & 14.7 & 17.9 \\
III (20.000 - 49.999) & 10.5 & 13.3 & 13.3 \\
IV (10.000 - 19.999) & 19.4 & 20.1 & 18.5 \\
V (5.000 - 9.999) & 13.1 & 13.5 & 14.7 \\
VI (below 5.000) & 9.5 & 6.2 & 8.2 \\
\hline
\end{tabular}

Source: own calculations

The great dependence of urban settlements on economic development was demonstrated in the period 1981-1991. Apart from the top 5 largest settlements, urban settlements with the strongest industries and the largest investments in the industry have grown the fastest. Examples of such urban settlements were Brčko (45\% growth) and Bugojno (38\% growth). The average population size of urban settlements was 13,450 in 1981, 16,550 in 1991 and 13,643 inhabitants in 2013. 
The largest changes in population number in the period 1991-2013 were in urban settlements with the majority Bosniak population. Sarajevo lost $23 \%$ of the population or Zenica $26.5 \%$, compared to 1991 . By contrast, urban settlements that were affected by far fewer war events (1992-1995), as in the Republic of Srpska entity, have more inhabitants in 2013 than 1991 (Bijeljina - an increase of 15.5\%). Figures 3, 4 and 5 show the largest urban settlements by population size in 1981, 1991 and 2013:

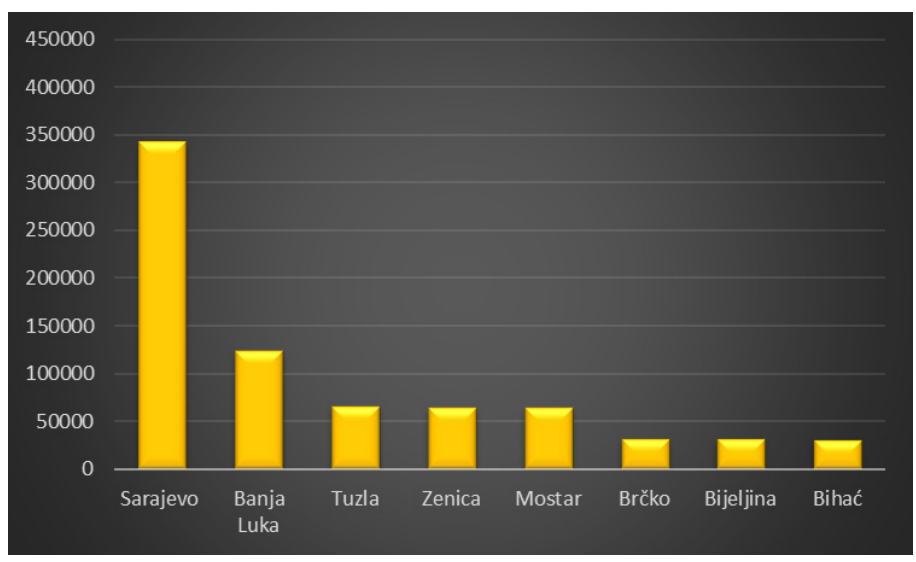

Figure 3: Largest urban settlements by population, 1981

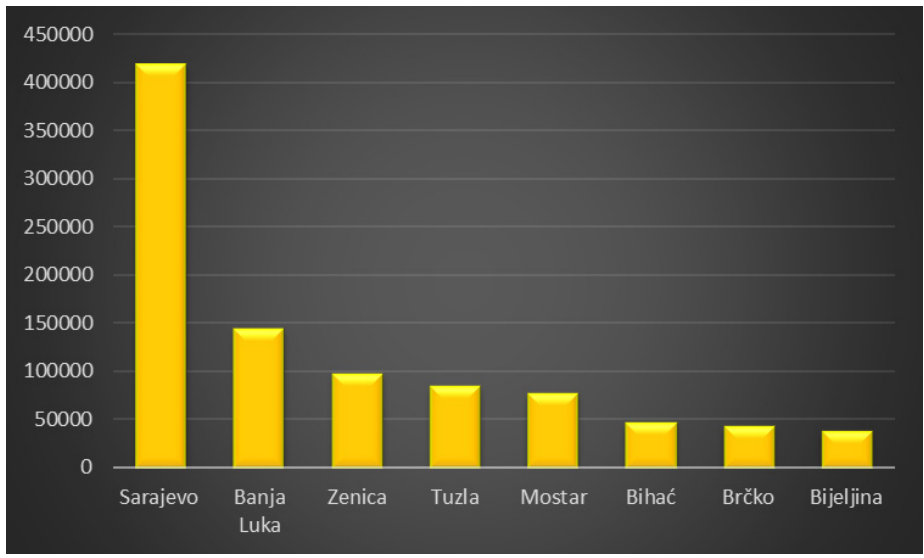

Figure 4: Largest urban settlements by population, 1991

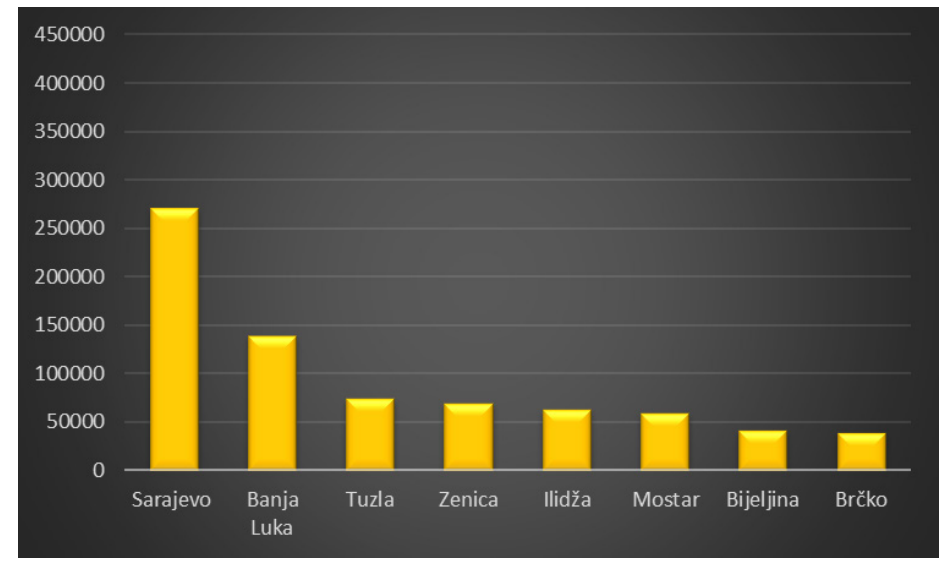

Figure 5: Largest urban settlements by population, 2013

In 2013, as well as in 1981 and 1991, urban settlements up to 5,000 inhabitants (VI class - microcities; Table 4) had the largest share of urban settlements. The share of these settlements in the total number of urban settlements in Bosnia and Herzegovina decreased from $43.7 \%$ in 1981 to $39.1 \%$ in 2013 . This points to a significant feature of the urban network of Bosnia and Herzegovina, which is mainly composed of small urban settlements. In contrast, in this urban settlement class, only $8.2 \%$ of the urban population lived in 2013 . The 
largest share of the urban population of Bosnia and Herzegovina of 27.3\%. lives in the two largest urban settlements (metropolises), Sarajevo and Banja Luka. In 2013, the urban system of Bosnia and Herzegovina had only 12 urban settlements with more than 20,000 inhabitants (10 in 1981 and 12 in 1991) (Figures 6, 7 and 8). The current urbanization is most influenced by the emigration of young skilled population to larger urban areas, and especially to European Union countries such as Germany.

Table 4: Class categories of cities (urban settlements) in Bosnia and Herzegovina, 2013.

\begin{tabular}{|c|c|c|}
\hline Class & Population & Urban settlement \\
\hline VI- microcity & (below 5.000) & $\begin{array}{r}\text { Hadžići,llijaš,Ključ,Gornji Vakuf, Velika Kladuša, Grude, Jablanica, Kladanj, Ugljevik,Ljubuški,Busovača,Ši- } \\
\text { povo,Stolac,Kneževo, Drvar, Orašje, Fojnica, Kiseljak, Bosanski Petrovac, Prozor, Čitluk, Breza, Neum,- } \\
\text { Vareš, Kupres, Srbac, Ljubinje, Olovo, Lopare, Srebrenica, Čajniče, Kalesija, Glamoč, Han Pijesak, Rudo, } \\
\text { Šekovići, Kalinovik, Kreševo, Bosansko Grahovo, } \\
\text { Istočno Novo Sarajevo, Trnovo, Istočni Stari Grad }\end{array}$ \\
\hline V - small city & $(5.000-9.999)$ & $\begin{array}{l}\text { Modriča, Novi Travnik, Odžak, Prnjavor, Zavidovići, Livno, Bratunac, Brod, Bileća, Kotor Varoš, Mrkonjić } \\
\text { Grad, Jajce, Teslić, Vlasenica, Donji Vakuf, Srebrenik, Rogatica, Banovići, Vitez, Posušje, Široki Brijeg, Mag- } \\
\text { laj, Čapljina, Sokolac, Tomislavgrad, Žepče, Laktaši, Višegrad, Gacko, Tešanj, Čelinac, Nevesinje, Šamac }\end{array}$ \\
\hline IV - mid city & $(10.000-19.999)$ & $\begin{array}{c}\text { Sanski Most, Živinice, Bugojno, Travnik, Gradiška, Cazin, Istočna Ilidža, Pale, Gračanica, Gradačac, Luka- } \\
\text { vac, Goražde, Kakanj, Derventa, Zvornik, Foča, Visoko, Konjic, Vogošća, Kozarska Dubica, } \\
\text { Bosanska Krupa, Novi Grad }\end{array}$ \\
\hline III - big city & $(20.000-49.999)$ & Bijeljina, Brčko, Bihać, Prijedor, Doboj, Trebinje \\
\hline II - regiopolis & $(50.000-99.999)$ & Tuzla, Zenica, Ilidža, Mostar \\
\hline I- metropolis & $(100.000+)$ & Sarajevo, Banja Luka \\
\hline
\end{tabular}

In the period 1981-2013, the number of urban settlements increased by 7 mainly due to changes in the separation of individual urban settlements from the urban settlement Sarajevo as a consequence of the Dayton Peace Agreement. Although the number of urban settlements in the period 1981-2013 increased by $6.8 \%$, the share of urban population in total increased by $8.9 \%$.
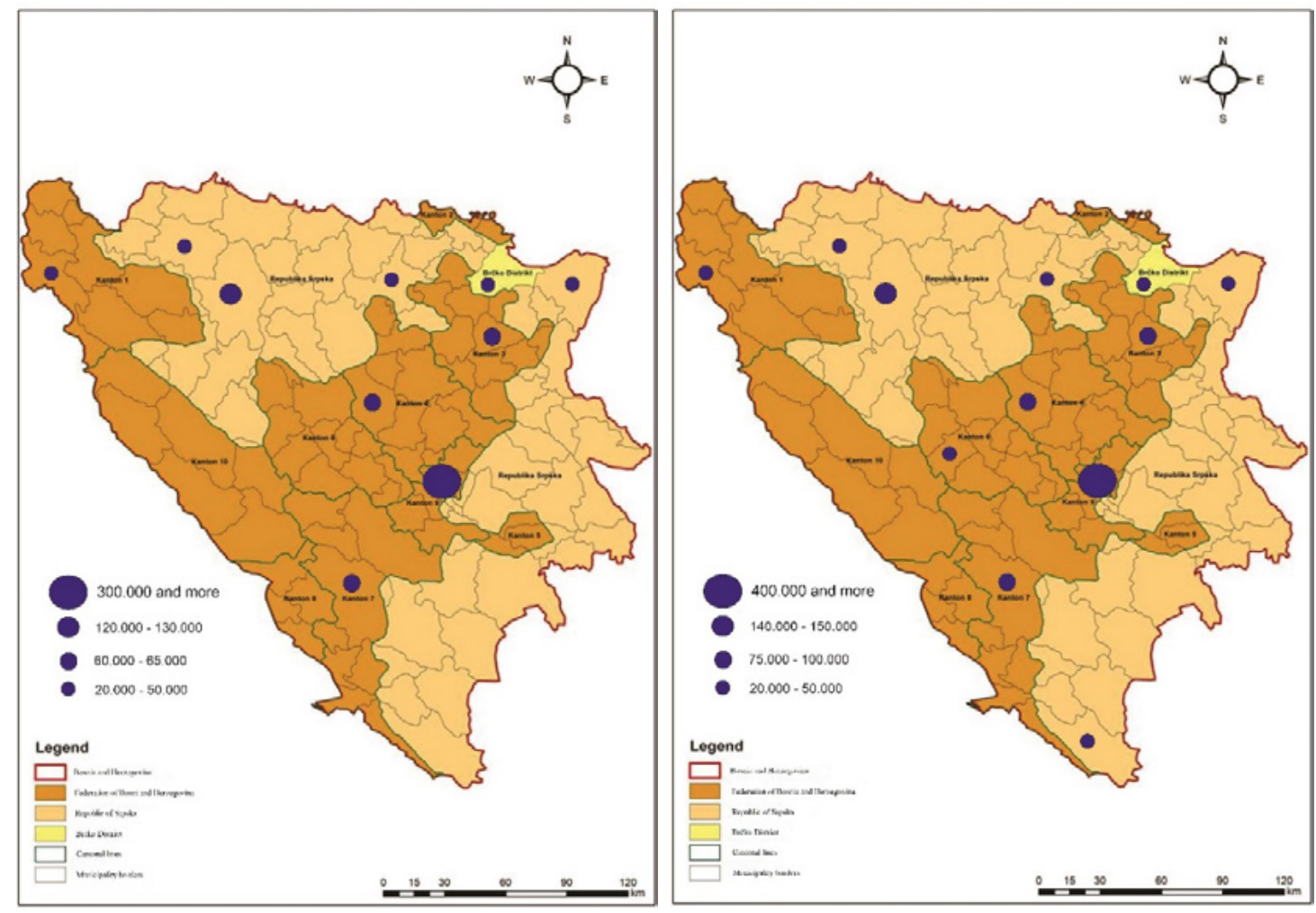

Figure 6: Location of urban settlements with Figure 7: Location of urban settlements with more than 20,000 inhabitants, 1981 more than 20,000 inhabitants, 1991 


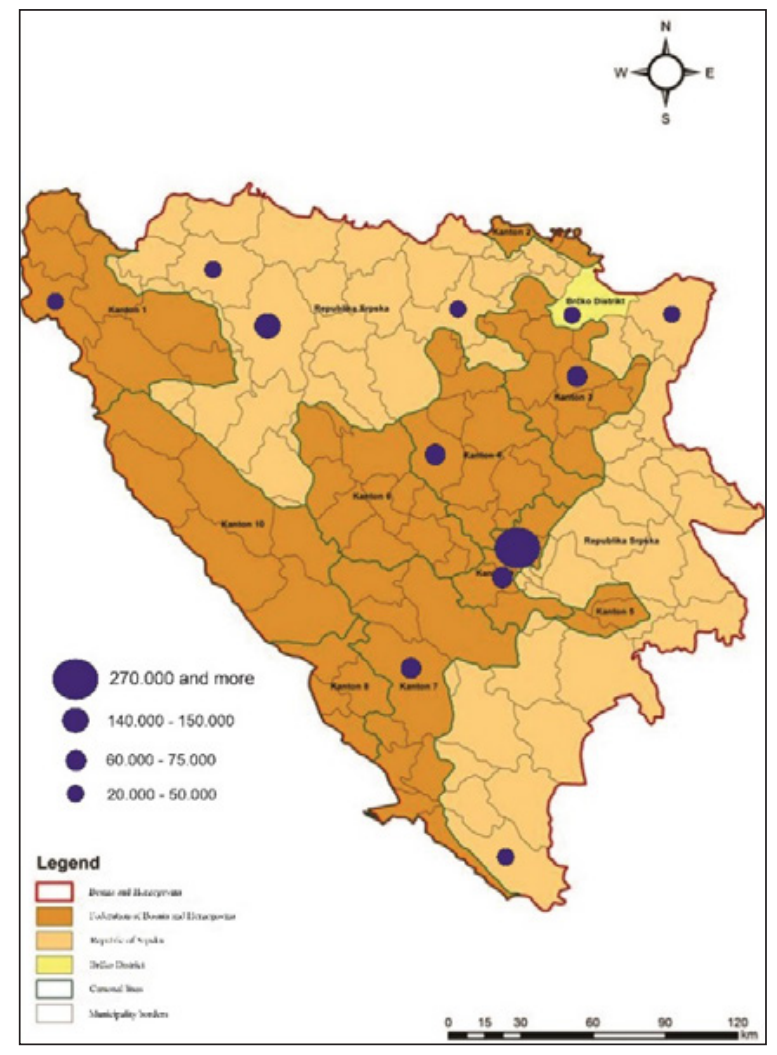

Figure 8: Location of urban settlements with more than 20.000 inhabitants, 2013

The rank size figures 9, 10 and 11 for Bosnia and Herzegovina for the year 1981, 1991 and 2013 has been presented with their logarithmic equations. The slope value of the theoretical rank size distribution is the magnitude of the forces of diversification divided by the forces of unification. Slope value as minus 1, is a balanced case in any urban system. Slope value as minus 1, indicates that in an urban system the forces of unification and diversification are equally distributed. It represents an integrated and stable urban system. The perfect fit of the urban population data of any urban system with the rank size model, indicates that the population of the smaller cities in that urban system follow a log liner relationship with the city with highest population. The straight line in the rank size graph indicates the state of equilibrium where the growth rate of each city size category stays the same in relation to the national trends. The slope being between minus 1 and 0 implies the dominance of the force of diversification. In this case there is a tendency for the development of a large number of smaller towns and cities. The slope value of less than minus 1 implies the dominance of the force of unification. The slope approximately fits the rule of size order, although during the period 1981-1991 the decrease in the number of urban settlements of the VI class and the increase in the number of urban settlements of the V class is noticeable, and then the reverse case due to emigration movements and the suffering of the population during the 1992-1995 war in the period 1991-2013.
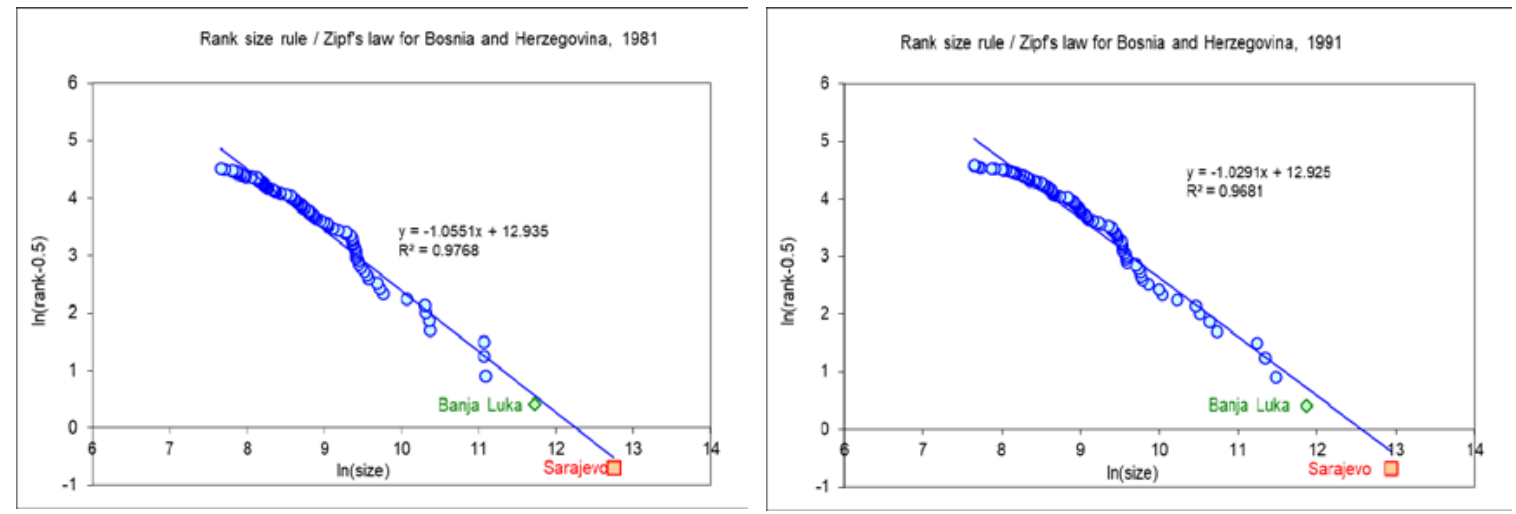

Figure 9: Rank size rule for Figure 10: Rank size rule for Bosnia and Herzegovina, 1981 Bosnia and Herzegovina, 1991 


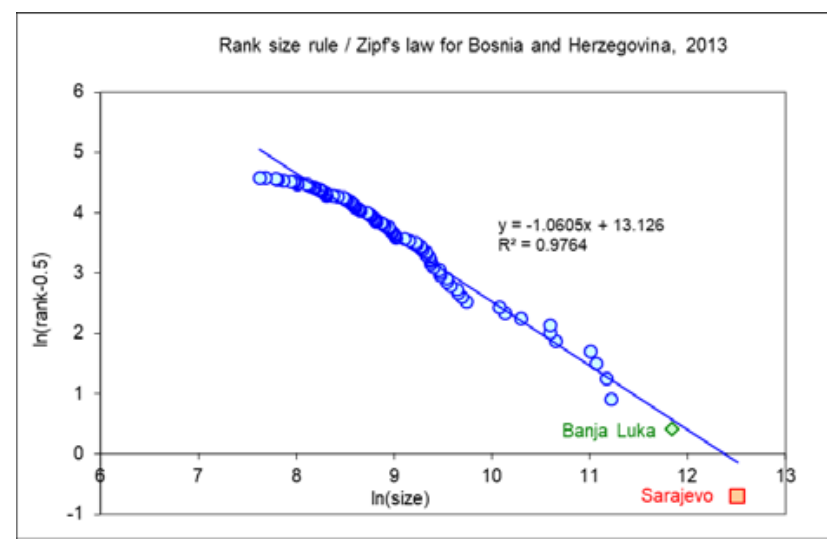

Figure 11: Rank size rule for Bosnia and Herzegovina, 2013

The urban system of Bosnia and Herzegovina is approximately following the rank size rule according to Zipf in the distribution of cities at national level. The second ranked city of Bosnia and Herzegovina does have the population as almost half the population of the largest city. Sarajevo is the largest urban settlement and in 2013 its population was 271.194 and the second largest city - Banja Luka's population in 2013 was 138.963, just little bit more population than $1 / 2$ of Sarajevo. Even the fifth ranked city Mostar had concentration of people very close to one-fifth of Sarajevo.

The slope for the census year 1981 shows really small discontinuities and deviations from the linear fit line. Two largest cities, Sarajevo and Banja Luka, at the lower end of the distribution were too large in 1981 far away from the fitted line. Similarly, there are other groups with slight discontinuities and deviations especially the group of next ten cities (except fifth Mostar) and then other small cities with less than 3,000 inhabitants. These deviations can be attributed to the strong emigration from smaller cities and to much stronger economic development of the capital city Sarajevo. The slope for the year 1991 shows that urban structure has evolved towards more linear distribution and especially in 2013 where urban settlements from 5-9 rank have larger size. However, it is still not completely linear. There are slight deviations from the linear fitted line. Actual data points in all three census years slightly deviate from fitted linear line. These plots to some extent suggest that the approximate form of Zipf's law seems to be confirmed for the size distribution of Bosnia and Herzegovina urban settlements. After that, we used equation to estimate Pareto exponent for each of the three census years. The estimated values of Pareto exponent in all census years are slightly larger than 1 . These results show that size distribution is slightly more uneven than the predicted by the Zipf's law. These results are consistent with the graphical representation which has shown slight deviations from the linear line. The estimated value of Pareto exponent decreased from 1.055 in 1981 to its lowest value 1.029 in 1991 and then increased to 1.060 in 2013. Together, these results show that Zipf's law does approximately hold for Bosnia and Herzegovina.

According to Zipf the slope of the theoretical rank size distribution is the magnitude of the force of diversification divided by that of the force of unification (Zipf, 1949). The regression coefficient measures the slope of the best-fit line. The slope value indicates the increasing role of forces of unification in the urban system, which resulted in the increasing domination of few large cities in the entire urban system. It shows that in contemporary period the forces of unification have become more dominant in determining the distribution of cities.

The polarisation of Bosnia and Herzegovina's urban development is reflected in the very dynamic monocentrism of the capital, i.e. the growing domination of Sarajevo and macro-regional centres such as Banja Luka, Tuzla and Mostar, which have become more intensive as a result of the war (migration of a large number of refugees and displaced persons). This has amplified the polarisation of urban development in said cities, while further provincialising other parts of Bosnia and Herzegovina, and stimulating further migration and concentration such as in the case of Trebinje and Bugojno. Before 1992, these cities were considered regional centres, a role which they have lost under the current political and territorial system established by the Dayton Peace Agreement.

As the strongest work centre, Sarajevo rests on the edge of the network, while some parts of the region lack stronger work centres. This is particularly evident in the eastern part of central Bosnia and Herzegovina. In addition to the asymmetry in terms of the size of work centres, the density of the urban network is also uneven. As far as network density is concerned, central Bosnia and Herzegovina stands out, particularly the road directions towards Zenica and Doboj. The poorest network, however, is observed in eastern Bosnia and Herzegovina. This will certainly influence the individual directions, especially the intensity and level of urbanisation thereof (Nurković and Gekić, 2011). 
Significant changes occurred in the top 20 urban settlements when comparing the situation in 2013 to 1981. The first 4 urban settlements maintained their rank, while Ilidža took over the 5th rank from Mostar by separation from Sarajevo. Brčko, Bihać, Doboj, Prijedor, Sanski Most, Bugojno, Travnik and Gradiška also lost their ranks for one to three positions. Derventa experienced the largest decline in what was once the top 20 ranked urban settlements from the 14th to the 25th position, mainly due to the large loss of Bosniak and Croat population and the collapse of industrial production (85\% fewer Bosniaks and Croats combined). In 2013, Živinice occupied the 14th place, and they used to be on the 37th, thanks to the proximity of Tuzla, one of the largest urban settlements of Bosnia and Herzegovina, and the development of industry. The urban settlement of Pale climbed to the 19th from the 92nd position, as it became one of the most important centers of development of the Republic of Srpska entity by the Dayton Peace Agreement.

The comparison of the urban system in Bosnia and Herzegovina for all these years can be done in a better way using the values in regression equations. These values have been used to interpret the implications of Bosnia and Herzegovina city size distribution on the urban system. The $\mathrm{R}^{2}$ value indicates that in 1981 there was $97.7 \%$ variance in the distribution of cities, which slightly decreased in 1991 to $96.8 \%$. It increased in the year 2013 to $97.6 \%$ variance in the distribution of cities. For all these years the theoretical relationship between rank and population of the cities as the hypothesis given by Zipf explains more than 96 percent of the variance. The major five urban settlements of Bosnia and Herzegovina remained the dominant in Bosnian urban system; they remained the top metropolitan cities after 1991: Sarajevo, Banja Luka, Tuzla, Zenica and Mostar. The large urban centres like Sarajevo act as the major magnets for the migrants after the 1995. These cities are becoming more popular recently. It is happening because these cities are getting more attention for the urban development, whereas the small and medium cities are not getting much attention by the governments.

Generally speaking, the distribution of urban settlements in Bosnia and Herzegovina according to the rank size rule is quite regular when compared to other developing countries. Since the post-World War II period, the urban system has been increasingly moving towards a state adjusted to the rank size rule in line with the economic development of the country, which is unfortunately disrupted by recent war events, and many urban settlements that were ranked medium-sized and small in 1991 today have a smaller population and an economy dominated by tertiary activities, and the industry has not been restructured. The analysis of the distribution of urban settlements according to the rank size rule order from 1991 and 2013 shows no significant deviations from the new, Dayton, political-geographical structure of Bosnia and Herzegovina, with the exception of the appearance of Ilidža, Cazin and Pale in the top 20 largest urban settlements. In the future, with the planned infrastructure projects, the growth of the top 8 largest urban settlements is expected to be much higher than in the rest. A survey of mobility in the ranking of urban settlements by size (1981-2013) reveals that the very top of the urban system hierarchy is far more stable than the part where small urban settlements are located. With greater investment especially in the industry, some urban settlements were moving from lower to higher hierarchical ranks.

The value of primacy index indicates that largest city was a primate city. The law of primate city is applicable for any of the census year. We used four city index for calculating urban primacy. In 1981, the primacy index was 0.57 , so that the urban system of Bosnia and Herzegovina was characterized by high primacy. Sarajevo, the largest urban settlement, had 2.8 times more residents than the second urban settlement in size, Banja Luka. In 1991, the primacy index was just under 0.56, with Sarajevo having 2.9 times more residents than Banja Luka. In 2013, the picture changed significantly, and with the separation of Ilidža as a separate municipality outside the urban settlement of Sarajevo, the urban system of Bosnia and Herzegovina is characterized by desirable urban primacy with a value of 0.49. Primacy index is in 20130.49 and we can say that Bosnia and Herzegovina have almost a primate city. Bosnia have more than one dominant city of economic and political importance, Sarajevo as its administrative and economic centre and Banja Luka as second economic centre and regional centre (Table 5).

Table 5: Four city index for Bosnia and Herzegovina, 1981-2013

\begin{tabular}{lc}
\hline Years & Four-city index \\
\hline 1981 & 0.57 \\
1991 & 0.56 \\
2013 & 0.49 \\
\hline
\end{tabular}

Source: own calculations 
In 1981, the urban settlements of Bosnia and Herzegovina were mostly occupied by industrial workers. In medium-sized and small urban settlements, the share of employees in industrial activities exceeded 55\% and in large urban settlements 35\%. Already in 1991, significant changes in the development of urban settlements were noticeable, with larger urban settlements having an increasing share of employees in tertiary activities (on average 60-70\%), while medium and small urban settlements slightly increased this share from 35\% to $40 \%$ (Census of population, 1981 and 1991). In the period 1992-1995, the industry of Bosnia and Herzegovina has experienced a major collapse. Important markets have been lost, large numbers of capable and educated workforce have left the country, manufacturing technology has been destroyed, devastated, obsolete, etc. The industry has not been able to return or successfully restructure, and tertiary activities still do not give much impetus to the development of urban settlements as it was done by industry until 1991.

In the eight largest urban settlements of Bosnia and Herzegovina in 2013, 257,365 inhabitants were employed of which only $18 \%$ worked in industrial activities and over $80 \%$ in tertiary activities. Over $80 \%$ of employees in tertiary sectors were in: Sarajevo $82.6 \%$ $(79,000)$, Banja Luka $80.2 \%(39,370)$ and Mostar 80.1\% (15,526) (Figure 12). The share of employees in tertiary activities is high in medium and small urban settlements, with an average of between $60-70 \%$, and examples are: Ljubuški 81.5\%, Neum 84.3\%, Vitez 77\%, Livno $76 \%$, Bugojno $69 \%$, Visoko $61 \%$ etc. In the tertiary sector in urban areas of Bosnia and Herzegovina, most of the population is employed in the wholesale and retail trade sector $16.8 \%$, and as much as $12.1 \%$ in the public administration and defense and compulsory social security sectors (this last share is sufficient to indicate that The Dayton Peace Agreement made the administrative structure of Bosnia and Herzegovina more complex; only 5.1\% employees were in 1991) (Census of population, 1991 and 2013).

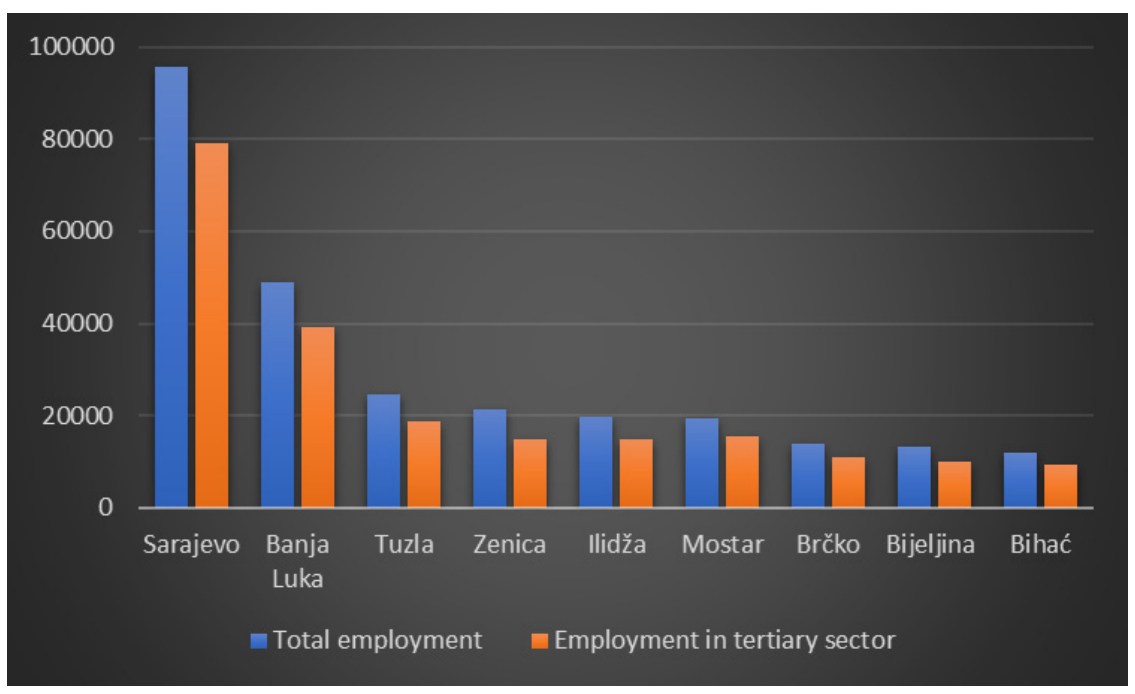

Figure 12: Employment in the largest urban settlements, 2013

The fundamental documents for establishing spatial planning in Bosnia and Herzegovina were the 1974 Law on Spatial Planning and the first Spatial Plan of Bosnia and Herzegovina 1981-2000. The Spatial Plan of Bosnia and Herzegovina which was adopted in 1981 brought together almost all domestic and most European experiences. The new Constitution of Bosnia and Herzegovina does not provide for spatial organisation and planning strategy at the state level, or even in the Council of Ministers of Bosnia and Herzegovina. The resulting situation is one in which these supremely important issues and the even more important framework for potential development are not legally regulated. Each entity plans and implements the most significant interventions in space on its own, without mutual coordination. Planning, in terms of both development and implementation, is defined at the level of the entities and the Brčko District. No national urban spatial strategy, no regional spatial strategy for Federation of Bosnia and Herzegovina.

Most municipalities have not developed or adopted their municipal spatial plan, mainly due to lack of financial means and the very complicated procedure for selecting developers of the planning document (USAID, 2012). The current situation in the reality is deformed by the existence of a line of delimitation between the newly established entities, between the Republic of Srpska and the Federation of Bosnia and Herzegovina, as well as its cantons. The entity Republic of Srpska has Banja Luka as main urban center. Much smaller urban centers are Trebinje, Bijeljina and Doboj. Entity Federation of Bosnia and Herzegovina is divided into 10 Cantons and each has its own urban center which creates a new divided modern network of urban settlements in Bosnia and Herzegovina. 
The breakdown of the former urban system conditioned by the entity border is reflected in 304 divided settlements and 34 newlyestablished municipalities. The only disintegration of urban settlement was in Sarajevo. Without significant financial and other investments, the population is steadily moving away into other European countries. Changes in urban structure caused by cantonal demarcation lines are not pronounced, but they are noticeable. Because of them, some urban settlements have lost their former functions and significance in the area. An example is the town of Bugojno, which, prior to the 1992-1995 war was a significant regional center with developed functions of industry, health, culture and sport. After establishing cantonal lines and setting Travnik as the seat of the Central Bosnia Canton, Bugojno loses its significance in the area and today is little different from urban settlements in the region.

In urban-geographical terms, the entity border has built the urban system that has been created for many years under specific historical and socio-economic conditions. The result of many years of development is the formation of a specific spatial structure of settlements of different hierarchical rank, conditioned by the spatial distribution of the population, economic contents and accompanying infrastructure. Through these processes, a network of urban settlements of different hierarchical rank was formed, which led to the spatial system of "urban reinforcement" as the dominant factor of socio-economic and other aspects of development of Bosnia and Herzegovina. This urban reinforcement is reflected in the spatial existence of the basic direction (Šamac-Doboj-Zenica-Sarajevo-Konjic-Mostar-Čapljina) and the lateral directions from west to north (Goražde-Sarajevo-Travnik-Jajce-Banja Luka-B.Gradiška) and in the northern part from west to east (Bihać-Prijedor-Banja Luka-Doboj-Tuzla-Zvornik).

Comparing such an urban network with a network of road and rail routes, one can notice their pronounced spatial connection. The urban network of Bosnia and Herzegovina played almost no role in the making of the Entities, neither their distances, nor their historical development. Given the complexity of the contemporary political-territorial and administrative division of Bosnia and Herzegovina, it is quite understandable that there has been a split in the settlement network and the urban system. Until the war (1992-1995), the existing network and settlement functions played almost no role in the formation of cantonal borders. Similarly, neither the distance of individual settlements from the center of the cantons nor their historical development and sense of belonging were taken into account. This disrupted the normal functioning of the urban system at the regional level (Mirić, 2006).

In 1991 I class of urban settlements are Sarajevo and Banja Luka just like in 2013, but there is one change in II class of urban settlements where beside Tuzla, Zenica and Mostar in 2013 we have Ilidža. Urban settlement Ilidža was integral part of Sarajevo urban settlement before 1995 and because of war is constituted as separate urban settlement despite in reality its integral and functional part of Sarajevo.

The post-1995 disintegration of the settlement system in Bosnia and Herzegovina is the result of the political and organisational arrangement set by the Dayton Peace Accord. It is reflected in disintegration of urban system, disintegration of large urban systems and disintegration of about $7 \%$ of all settlements. The consequences of the disintegration are many, and they are very complex and affect almost all components of socio-economic development. The disintegration of the urban system led to the disintegration of the urban network, and of the functional links and relations between the settlements that were established a long time ago. The political and territorial organisation established by the Dayton Agreement disintegrated the backbone of urban " $T$ " system of Bosnia and Herzegovina transversely (Šamac-Doboj-Zenica-Sarajevo-Mostar-Čapljina) and longitudinally (Bihać-Prijedor-Banja Luka-Doboj-Tuzla-Zvornik). Large urban systems such as Sarajevo and Doboj were also disintegrated (Nurković, 2006).

Existing political and territorial organization of Bosnia and Herzegovina, based on the Dayton Peace Agreement from 1995, is in complete disharmony with its urban and regional-geographic structure, which relies on its natural physiognomy, the economic function and nodal differentiation. Entity line was created as a compromise to stop the war in Bosnia and Herzegovina 1992-1995 year. This line clip physiognomic units and tore previously self-sustaining functions of nodal-functional regions, which have primarily relied on its natural physiognomy. Negative processes of political-territorial arrangement compounded by cantonal regulation of the Federation of Bosnia and Herzegovina, which is crisscrossed together previously self-sufficient geographic regional and sub regional entities.

Dayton inter-entity and cantonal lines are a disintegrating factor of physiognomic predejtonic urban and regional units that, apart from the relief structure, have disintegrated river basins, river network, diversity landscape structure, functional linkage of natural resources with processing capacities, centers of economic development to predetermined units and adjacent complementary centers of economic development (Spahić and Jahić, 2014). 
The disintegration of integrative urban and regional development of Bosnia and Herzegovina has negative tendencies to the overall and individual strategy of its development, which has been clearly shown in the last 23 years of its Dayton political-legal arrangement. Political lines of delimitation are not geographic to be called political-geographic and, therefore, have no geographic meaning for potential regionalization of the state territory.

\section{CONCLUSION}

The structure and hierarchy of the urban system of Bosnia and Herzegovina, described in the previous section, includes three basic conclusions:

- The clear stability of the system at the top of the hierarchy, due to the large difference between the first urban settlement and other urban settlements, was partially disrupted by the 1992-1995 war.

- Very slow mobility of medium-sized urban settlements (from 10,000 to 20,000 inhabitants) is present throughout the whole period (1981-2013). Population growth rates in small urban settlements do not compete with medium-sized urban settlements. Despite the significant population loss in the period 1991-2013, medium-sized urban settlements maintained their relative hierarchical rank.

- There is noticeable dynamism at the level of small urban settlements (with less than 10,000 inhabitants) in both size and hierarchical rank. Spatial reconfiguration with respect to the war events (1992-1995) is far less regionally represented in the urban settlements of the Republic of Srpska entity than in the Entity of Federation of Bosnia and Herzegovina, which is noticeable in the hierarchical rank of this group of settlements.

The results of the research show that despite the political and economic transformations in the last 30 years, there has been an approximate adjustment of the distribution of urban settlements to the rank size rule at the national level due to the existence of a wellestablished urban system that has been developing for centuries. Also, mobility in the ranking of urban settlements from 1981-2013 has been analyzed in detail.

The urban system of Bosnia and Herzegovina in 2013 is characterized by desirable urban primacy. Sarajevo has nearly twice as many inhabitants as the urban settlement of Banja Luka. Most of the urban population, 58.5\%, is concentrated in 12 urban settlements with more than 20,000 inhabitants ( $11 \%$ of urban settlements). In $89 \%$ of urban settlements lives $41.5 \%$ of urban population of Bosnia and Herzegovina.

The results of the research may be useful to geographers, regional and spatial planners, economists, sociologists, policy makers, etc. We also hope that the research will contribute to a better knowledge of the urban geography of Bosnia and Herzegovina. 


\section{REFERENCES}

Bakaršić, S. (1961). O nekaternih činiteljih urbanizacije v Bosni in Hercegovini v turškem obdoblju. Geografski obzornik 8(1), 10-19. Bakaršić, S. (1973). Još jednom o procesu urbanizacije za turskog doba u Bosni i Hercegovini. Geografski pregled 14-15, 214-230. Bašić, M. (2006): Osnove ratne ekonomije - s osvrtom na rat u Bosni i Hercegovini 1992.-95. godine, Ekonomski pregled 57(1-2), 130-145. Berry, B. J. (1964). Cities as Systems within Systems of Cities. Papers of the Regional Science Association, 13, $147-163$.

Berry, B. J., Garrison, W. L. (1958). Alternate Explanations of Rank-size Relations. Annals of the Association of American Geographers 48(1), 83-91. Bigotte, J., Antunes, A., Krass, D., Berman, O. (2014). The Relationship between Population Dynamics and Urban Hierarchy: Evidence from Portugal. International Regional Science Review 37, 149-171.

Brenner, N., Schmid, C. (2015). Towards a new epistemology of the urban? City, 19(2-3), 151-182.

Census of population of Bosnia and Herzegovina, 1879, 1885, 1895, 1910, 1921, 1931, 1948, 1953, 1961, 1971, 1981, 1991, 2013. Agency for Statistics of Bosnia and Herzegovina, Sarajevo.

Chen, Y. (2016). The evolution of Zipf's law indicative of city development. Physica A: Statistical Mechanics and its Applications, $443,555-567$. Chen, Z., Lu, M. (2015). Urban Systems and Urban Development in the People's Republic of China. ADBI Working Paper Series 52, 1-23.

Das, R. J., Dutt, A. K. (1993). Rank Size Distribution and Primate City Characteristics in India: A Temporal Analysis. GeoJournal, $29(2), 125-137$. Dimou, M., Schaffar, A. (2009). Urban Hierarchies and City Growth in the Balkans. Urban Studies 46(13), 2891-2906.

Dokmeci, V. F. (1986). Turkey: Distribution of cities and change over time. Ekistics, 13-17.

Đerčan, B., Radaković, M., Ostojić, M., Mirković, M., Obrenov, S., Vozar, J. (2017). Urban hierarchy in Serbia. Researches Reviews of the Department of Geography, Tourism and Hotel Management, 46(1), 11-23.

Gabaix, X. (1999). Zipf's law for cities: An explanation. Quarterly Journal of Economics, 119, 739-767.

Gabaix, X., Ibragimov, R. (2011). Rank-1/2 a simple way to improve the OLS estimation of tail exponents. Journal of Business Economic and Statistics 29(1), 24-39.

Gabaix, X., Ioannides, Y. M. (2004). The evolution of city size distributions. In: Handbook of Regional and Urban Economics. 4 ; Chapter 53. Gekić, H., Bidžan-Gekić, A. 2016. Urbanization in Bosnia and Herzegovina: A case study of Uskopaljska Valley. Theoretical \& Applied Science 38(6), Lancaster, 147-154.

Gregory, D., Urry, J. (1985). Social Relations and Spatial Structure. London: Macmillan.

Hadar, Y., Pines, D. (2004). Population Growth and Its Distribution between Cities: Positive and Normative Aspects. Regional Science and Urban Econonomics, 34, 125-154.

Hadžibegović, I. (2004). Bosanskohercegovački gradovi na razmeđu 19. i 20. stoljeća. Sarajevo: Institut za istoriju.

Harvey, D. (1973). Social justice and the city. London: Edward Arnold.

Ibrahimagić, O. (2015). Državnopravni kontinuitet Bosne i Hercegovine i pitanje nacije. Zbornik radova Pravnog fakulteta u Tuzli, $2,148-158$.

Jażdżewska, I. (2017). Spatial and dynamic aspects of the rank-size rule method. Case of an urban settlement in Poland. Computers, Environment and Urban Systems 62, 199-209.

Jefferson, M. (1939). The law of the primate city, Geographical Review, 29(2), 226-232.

Kamberović, H. (1998). Osnovna obilježja razvoja društva u Bosni i Hercegovini od 1945. do 1953.godine. Časopis za suvremenu povijest 30(2), 359-376.

Kovačević-Kojić, D. (1978). Gradska naselja srednjovjekovne bosanske države. Sarajevo: Veselin Masleša.

Kumari, A. (2015). City Size Distributions and Hierarchy among Cities in India. The Journal of Development Practice, 2, $26-34$.

Kundak, S., Dökmeci, V. (2018). A Rank-Size Rule Analysis of The City System at The Country and Province Level in Turkey. ICONARP, International Journal of Architecture \& Planning 6 (1), 77-98.

Lefebvre, H. (1996). The right to the city. In H. Lefebvre. Writings on cities (2nd ed.). Cambridge: Blackwell.

Mehta, S. K. (1964). Some Demographic and Economic Correlates of Primate Cities: A Case for Revaluation. Demography, 1(1), 136-147.

Ministry of human rights and refugees of Bosnia and Herzegovina (2006). Stambeni i urbani profil Bosne i Hercegovine. Sarajevo.

Mirić, R. (2006). Uticaj savremenog političko-teritorijalnog ustroja na promjene u naseobinskom sistemu Bosne i Hercegovine s posebnim osvrtom na sarajevsko naselje Dobrinja. Annales, Series historia et sociologia, 16(1), 221-232.

Mokhtar, B. (2013). Urban System and Primate City in Oman. British Journal of Arts and Social Sciences 13(1), 84-95.

Mutlu, S. (1989). Urban Concentration and Primacy Revisited: An Analysis and Some Policy Conclusions. Economic Development and Cultural Change, 37(3), 611-639.

Nitsch, V. (2005). Zipf zipped. Journal of Urban Economics, 57(1), 86-100.

Nurković, R., Gekić, H. (2011). New Spatial Development Processes of Urbanization of Sarajevo, Journal of Settlements and Spatial Planning, 2 , 109-114. 
Nurković, S. (2006). Suvremeni sociogeografski problemi regionalnog razvoja Bosne i Hercegovine. Annales, Series historia et sociologia, 16(1), 203-212.

Pašalić, E. (1960). Antička naselja i komunikacije u Bosni i Hercegovini. Sarajevo: Zemaljski muzej Sarajevo.

Richardson, H. (1973). The Economics of Urban Size. Gower, Massachusetts 1973.

Sarkar, S., Maji, S. (2013), An Analysis of Urban Primacy: The Case of Kolkata. Indian Journal of Applied Research, 3(3), $158-162$.

Soo, T. K. (2005). Zipf's Law of Cities: A Cross Country Investigation. Regional Science and Urban Economics, 35(3), $239-263$.

Spahić, M., Jahić, H. (2014). Geographical regionalizations of Bosnia and Herzegovina in the light of Euro-Atlantic integrations. Acta geographica Bosniae et Herzegovinae 1, 35-52.

Sućeska, A. (1968). Neke specifičnosti istorije Bosne pod Turcima, Prilozi 4, 42-54.

The World Factbook CIA (2018): Retrieved from https://www.cia.gov/library/publications/the-world-factbook

USAID (2012). Priručnik iz prostornog planiranja. Governance Accountability Project. Sarajevo.

Vresk, M. (1990). Osnove urbane geografije. Zagreb: Školska knjiga.

Waugh, D. (2000). Geography: An integrated approach. Cheltenham: Nelson Thornes.

Yong-Hyun, K., Rennie, S. J (2010). Cities and Economies. Routledge, London.

Yousuf, T., Shah, S. A. (2014). An analysis of urban primacy in Himalayan settlements: the case of Srinagar City of Jammu \& Kashmir. International Journal of Recent Scientific Research, 5(9), 1670-1674.

Zipf, K. (1949). Human Behavior and the Principle of Least Effort. Cambridge, MA: Addison-Wesley. 